\title{
Distinct Expression Pattern of Circulating MiRNA-1, MiRNA-133a and Mirna-133b in STEMI and NSTEMI
}

\author{
Sirküle MiRNA-1, MiRNA-133a ve MiRNA-133b' nin STEMI ve NSTEMI' deki \\ Farkıı Ekspresyon Özellikleri
}

\author{
Gulcin Tezcan ${ }^{1}$, Fatma Ozdemir ${ }^{*}$, Gulsah Cecener $^{3}$, Secil Ak Aksoy ${ }^{3}$, Berrin Tunca ${ }^{3}$, Erol \\ Armagan $^{2}$, Ozlem Koksal ${ }^{2}$, Pinar Cinar Sert ${ }^{4}$
}

${ }^{1}$ Kazan Federal University, Institute of Fundamental Medicine and Biology, Kazan, Russia

${ }^{2}$ Uludag University, Faculty of Medicine, Emergency Medicine Department, Bursa, Turkey

3 Uludag University, Faculty of Medicine, Medical Biology Department, Bursa, Turkey

${ }^{4}$ Cekirge Government Hospital, Emergency Medicine Department, Bursa, Turkey

\begin{abstract}
Objective: miR-1 miR-133a and miR-133b release into the circulation during the early stages of acute coronary syndrome (ACS). However, their discriminative expression pattern in ST-elevation myocardial infarction (STEMI) and Non-STelevation myocardial infarction (NSTEMI) remains unknown. The present study aims to characterize and compare the circulating miR-1, miR-133a and miR-133b expression levels in peripheral blood samples of ACS patients to determine their discriminative expression pattern of STEMI or NSTEMI.

Material and Methods: Peripheral blood samples were taken from 54 patients with ACS (27 STEMI, 27 NSTEMI) and 20 healthy volunteers. The expression levels of miR-1, miR-133a and miR-133b were measured by qRT-PCR. The association of miRNA expressions and characteristics of STEMI and NSTEMI patients were evaluated using a web-based program "RT2 Profiler PCR Array Data Analysis".

Results: The expression levels of miR-1, miR-133a and miR$133 \mathrm{~b}$ were higher in ACS than the control group $(\mathrm{P}<0.05)$. However, the expression pattern of miRNAs differs between STEMI and NSTEMI patients, time-dependently. While miRNA expressions were in positive correlation with CK-MB in STEMI, they were in negative correlation in NSTEMI patients.

Conclusion: Our findings suggest that the dynamic expression of miR-1, miR-133a and miR-133b could predict the severity and progression of coronary heart disease in ACS patients. Advanced functional studies and larger cohort validations are required.
\end{abstract}

Key Words: Acute Coronary Syndrome, STEMI, NSTEMI, circulating miRNA

\section{Introduction}

Acute coronary syndrome (ACS) is one of the leading culprits of death worldwide. ACS refers to a spectrum

\section{ÖZET}

Amaç: Akut koroner sendrom (ACS)'un erken evrelerinde kanda sirküle miR-1 miR-133a ve miR-133b ekspresyonlarının artış gösterdiği saptanmıştır. Ancak, bu miRNA'ların ST yükselmeli miyokard enfarktüsü (STEMI) ve ST yükselmesi olmayan miyokard enfarktüsü (NSTEMI) olgularında ekspresyon özelliklerindeki olası farklılıklar bilinmemektedir. Çalışmamızın amacı, sirküle miR-1, miR133a ve miR-133b'nin STEMI ve NSTEMI' deki farklı ekspresyon özelliklerinin araştırılmasıdır.

Yöntem ve Gereçler: 54 ACS olgusundan (27 STEMI, 27 NSTEMI) ve 20 sağlıklı gönüllüden periferik kan örnekleri alınd. qRT-PCR yöntemi kullanılarak miR-1, miR-133a ve miR-133b'nin periferik kandaki ekspresyon seviyeleri ölçüldü. miRNA ekspresyon analizi sonuçları ile STEMI ve NSTEMI arasındaki ilişki "RT2 Profiler PCR Array Data Analysis" ağ tabanlı yazılımı kullanılarak değerlendirildi.

Bulgular: ACS olgularında miR-1, miR-133a ve miR-133b'nin ekspresyon seviyelerin kontrol grubuna göre daha yüksek olduğu belirlendi $(\mathrm{P}<0.05)$. Ancak STEMI ve NSTEMI olgularında miRNA ekspresyon profilinin zamana bağımlı olarak farklılık gösterdiği gözlendi.

STEMI olgularında miRNA ekspresyon seviyelerinin CK-MB ile pozitif korelasyon gösterdiği, NSTEMI olgularında ise negatif korelasyon gösterdiği saptandı.

Sonuç: Çalışmamız miR-1, miR-133a ve miR-133b'deki ekspresyon değişimlerinin, ACS olgularında koroner kalp hastalığının şiddetini ve ilerlemesini öngörebileceğini göstermekle birlikte, bulgularımızın fonksiyonel çalışmalarla ve daha geniş hasta gruplarında desteklenmesi gerekmektedir.

Anahtar Kelimeler: Akut koroner sendrom, STEMI, NSTEMI, sirküle miRNA

of conditions compatible with acute myocardial ischemia and/or infarction that may arise from a sudden reduction in the coronary blood flow. Symptoms which occur because of a partial or total 
Table 1. Clinical characteristics of enrolled ACS patients

\begin{tabular}{|c|c|c|c|}
\hline & STEMI & NSTEMI & Total \\
\hline & $\mathrm{N}(\%)$ & $\mathrm{N}(\%)$ & $\mathrm{N}(\%)$ \\
\hline \multicolumn{4}{|l|}{ Gender } \\
\hline Male & $21(77.8)$ & $19(70.4)$ & $40(74.1)$ \\
\hline Female & $6(22.2)$ & $8(29.6)$ & $14(25.9)$ \\
\hline \multicolumn{4}{|c|}{ Coronary heart disease } \\
\hline$(+)$ & $6(22.2)$ & $12(44.4)$ & $18(33.3)$ \\
\hline$(-)$ & $21(77.8)$ & $15(55.6)$ & $36(66.7)$ \\
\hline \multicolumn{4}{|l|}{ Obesity } \\
\hline$(+)$ & $0(0.0)$ & $2(7.4)$ & $2(3.7)$ \\
\hline$(-)$ & $27(100.0)$ & $25(92.6)$ & $52(96.3)$ \\
\hline \multicolumn{4}{|c|}{ Arterial hypertension } \\
\hline$(+)$ & $7(25.9)$ & $9(33.3)$ & $16(29.6)$ \\
\hline$(-)$ & $20(74.1)$ & $18(66.7)$ & $38(70.4)$ \\
\hline \multicolumn{4}{|l|}{ Hyper lipid } \\
\hline$(+)$ & $0(0.0)$ & $3(11.1)$ & $3(5.6)$ \\
\hline$(-)$ & $0(0.0)$ & $24(88.9)$ & $51(94.4)$ \\
\hline \multicolumn{4}{|l|}{ Diabetes mellitus } \\
\hline$(+)$ & $7(25.9)$ & $7(25.9)$ & $14(25.9)$ \\
\hline$(-)$ & $20(74.1)$ & $20(74.1)$ & $40(74.1)$ \\
\hline \multicolumn{4}{|l|}{ Family hisyory } \\
\hline$(+)$ & $2(7.4)$ & $3(11.1)$ & $5(9.3)$ \\
\hline$(-)$ & $25(92.6)$ & $24(88.9)$ & $49(90.7)$ \\
\hline \multicolumn{4}{|l|}{ Smoking } \\
\hline$(+)$ & $12(44.4)$ & $3(11.1)$ & $15(27.8)$ \\
\hline$(-)$ & $15(55.6)$ & $24(88.9)$ & $39(72.2)$ \\
\hline \multicolumn{4}{|c|}{$\begin{array}{l}\text { Admition time to emergency } \\
\text { department }\end{array}$} \\
\hline $1 \mathrm{~h}$ & $9(33.3)$ & $10(37.1)$ & $19(35.2)$ \\
\hline $2 \mathrm{~h}$ & $4(14.8)$ & $3(11.1)$ & $7(12.9)$ \\
\hline $3-5 \mathrm{~h}$ & $11(40.8)$ & $4(14.8)$ & $15(27.8)$ \\
\hline $6-12 \mathrm{~h}$ & $3(11.1)$ & $4(14.8)$ & $7(12.9)$ \\
\hline $13-24 \mathrm{~h}$ & $0(0.0)$ & $6(22.2)$ & $6(11.2)$ \\
\hline
\end{tabular}

blockage of a coronary artery and cause myocardial ischemia (cells starving of oxygen) OR infarction (cell death) (1). According to Turkish Statistical Institute, ACS is responsible for almost $40 \%$ of death due to heart diseases in Turkey (2).

WHO report that the diagnostic criteria of ACS are a typical chest pain evocative of myocardial ischemia, changes in ST-segment or new Q waves development and altered cardiac enzymes (3). The majority of emergent hospitalizations for ACS include ST segment-elevation myocardial infarction (STEMI) and Non-ST segment-elevation myocardial infarction (NSTEMI) (4). Currently cardiac troponins and creatine kinase $\mathrm{MB}$ (CK-MB) fraction are the most common biomarkers used for the diagnosis of this disease in clinical practice. In STEMI there is an elevation of CK-MB fraction, troponin I or $\mathrm{T}$ above the cut off levels. NSTEMI is mostly because of necrosis of myocardium with the release of biochemical markers Troponins I or T and CK-MB $(5,6)$. Although huge progress has been observed regarding diagnosis, treatment, and prognosis of ACS recently if the patient does not have symptoms, such as chest pain or atypical pain, STEMI or NSTEMI are may be unpredictable $(7,8)$.

Recently, microRNAs (miRNAs), which are involved in the post-transcriptional regulation of genes, also come into focus to understand the molecular biology 
Table 2. MiRNA expression status of ACS cases

\begin{tabular}{|c|c|c|c|c|}
\hline & & miR-1 & miR-133a & miR-133b \\
\hline \multirow{6}{*}{$1 \mathrm{~h}$} & $2^{\wedge}(-\operatorname{Avg} .(\operatorname{Delta}(\mathrm{Ct}))$ & 0.0084 & 0.0005 & 0.0004 \\
\hline & Fold Change & 8.06 & 3.27 & 3.42 \\
\hline & Fol Regulation & 8.06 & 3.27 & 3.42 \\
\hline & $95 \% \mathrm{CI}$ & $(0.00001,23.09)$ & $(0.00001,7.36)$ & $(0.00001,7.36)$ \\
\hline & $* \mathrm{P}$ value & 0.22044 & 0.14797 & 0.34033 \\
\hline & $2^{\wedge}(-\operatorname{Avg} .(\operatorname{Delta}(\mathrm{Ct}))$ & 0.0065 & 0.0003 & 0.0002 \\
\hline \multirow{3}{*}{$2 \mathrm{~h}$} & Fold Change & 6.22 & 2.45 & 2.25 \\
\hline & Fol Regulation & 6.22 & 2.45 & 2.25 \\
\hline & $95 \% \mathrm{CI}$ & $(0.00001,25.66)$ & $(0.00001,6.80)$ & $(0.00001,5.87)$ \\
\hline \multirow{7}{*}{$3-5 \mathrm{~h}$} & $* \mathrm{P}$ value & 0.01203 & 0.26607 & 0.75533 \\
\hline & $2^{\wedge}(-\operatorname{Avg} \cdot(\operatorname{Delta}(\mathrm{Ct}))$ & 0.0065 & 0.0003 & 0.0002 \\
\hline & Fold Change & 6.24 & 1.80 & 1.64 \\
\hline & Fold Regulation & 6.24 & 1.80 & 1.64 \\
\hline & $95 \% \mathrm{CI}$ & $(0.00001,16.72)$ & $(0.00001,3.84)$ & $(0.00001,3.37)$ \\
\hline & $* \mathrm{P}$ value & 0.00609 & 0.89357 & 0.31499 \\
\hline & $2^{\wedge}(-\operatorname{Avg} \cdot(\operatorname{Delta}(\mathrm{Ct}))$ & 0.0202 & 0.0013 & 0.0008 \\
\hline \multirow{3}{*}{$6-12 \mathrm{~h}$} & Fold Change & 19.35 & 9.55 & 7.22 \\
\hline & Fol Regulation & 19.35 & 9.55 & 7.22 \\
\hline & $95 \%$ CI & $(0.00001,53.81)$ & $(0.00001,22.05)$ & $(0.00001,16.39)$ \\
\hline \multirow{6}{*}{$12-24 \mathrm{~h}$} & $* \mathrm{P}$ value & 0.00012 & 0.02949 & 0.20799 \\
\hline & $2^{\wedge}(-\operatorname{Avg} \cdot(\operatorname{Delta}(\mathrm{Ct}))$ & 0.0019 & 0.0001 & 0.0001 \\
\hline & Fold Change & 1.78 & 1.04 & 1.29 \\
\hline & Fol Regulation & 1.78 & 1.04 & 1.29 \\
\hline & $95 \% \mathrm{CI}$ & $(0.00001,6.58)$ & $(0.00001,2.60)$ & $(0.00001,3.30)$ \\
\hline & $* \mathrm{P}$ value & 1.78280 & 1.03810 & 1.28890 \\
\hline
\end{tabular}

$* \mathrm{P}$ values evaluated by independent sample $\mathrm{T}$ test with comparing control samples $2^{\wedge}(-\mathrm{Avg}$.(Delta(Ct))

$2^{\wedge}$ (-Avg.(Delta(Ct)) of control group; miR-1: 0.001046, miR-133a: 0.000139 and miR-133b: 0.000109

of ACS better. miRNAs are involved in the pathogenesis of the heart, and their expression levels change considering the pathologic conditions (9). Among the miRNAs implicated in cardiac diseases, miR-1, miR-133a and miR-133b have also been detected in the plasma or serum of ACS patients. Thus, the miRNAs are of particular interest to clarify the difference between the mechanism of STEMI and NSTEMI. The present study aims to characterize and compare the circulating miR-1, miR-133a and miR$133 \mathrm{~b}$ expression levels in peripheral blood samples of ACS patients to determine their discriminative expression pattern of STEMI or NSTEMI.

\section{Material and Methods}

Study Cohort: A total of 54 patients with ACS (40 males and 14 females; $60.94 \pm 1.79$ years old) participated in this study. 20 healthy volunteers were control subjects $(43.15 \pm 1.48$ years old $)$.
In line with the guidelines, ACS was diagnosed considering the combination of various parameters, including ischemic symptoms plus increased cardiac troponin T, CK-MB levels, chest pain that lasts for N30 min, pathological Q waves or ST-segment elevation or depression. STEMI diagnosis was reached considering ECG criteria, NSTEMI on troponin levels with the symptoms of ischemia. The patients involved in this study if only they admitted to the emergency department within first 24 hours of chest pain feeling. The time of admission after chest pain feeling was recorded for all patients and they classified accordingly. Patients applied to emergency department with chest pain and have the final diagnosis except STEMI or NSTEMI (such as stable angina, unstable angina pectoris, pulmonary embolism, aorta dissection, pericarditis) and under the age of 18 were excluded from this study. This study was approved by the Local Ethics Committee (2011$2 / 21$ and 2011-2/24) and conducted in line with the 
Table 3. Time dependent miRNA expressions in STEMI cases

\begin{tabular}{|c|c|c|c|c|}
\hline & & miR-1 & miR-133a & miR-133b \\
\hline \multirow[t]{5}{*}{$1 \mathrm{~h}$} & $2^{\wedge}(-\operatorname{Avg} .(\operatorname{Delta}(\mathrm{Ct}))$ & 0.0002 & 0.0001 & 0.0001 \\
\hline & Fold Change & 0.17 & 0.64 & 0.96 \\
\hline & Fol Regulation & -5.87 & -1.55 & -1.04 \\
\hline & $95 \% \mathrm{CI}$ & $(0.00001,0.40)$ & $(0.00001,1.35)$ & $(0.00001,2.19)$ \\
\hline & $* \mathrm{P}$ value & 0,19630 & 0,22561 & 0,34616 \\
\hline \multirow[t]{5}{*}{$2 \mathrm{~h}$} & $2^{\wedge}(-\operatorname{Avg} \cdot(\operatorname{Delta}(\mathrm{Ct}))$ & 0.0004 & 0.0001 & 0.0001 \\
\hline & Fold Change & 0.38 & 0.63 & 0.65 \\
\hline & Fol Regulation & -2.65 & -1.59 & -1.53 \\
\hline & $95 \% \mathrm{CI}$ & $(0.00001,1.54)$ & $(0.00001,1.66)$ & $(0.00001,1.56)$ \\
\hline & $* \mathrm{P}$ value & 0.07963 & 0.46856 & 0.41496 \\
\hline \multirow[t]{5}{*}{$2-6 \mathrm{~h}$} & $2^{\wedge}(-\operatorname{Avg} \cdot(\operatorname{Delta}(\mathrm{Ct}))$ & 0.0031 & 0.0003 & 0.0001 \\
\hline & Fold Change & 2.98 & 1.87 & 1.36 \\
\hline & Fol Regulation & 2.98 & 1.87 & 1.36 \\
\hline & $95 \% \mathrm{CI}$ & $(0.00001,8.49)$ & $(0.00001,4.25)$ & $(0.00001,2.90)$ \\
\hline & $* \mathrm{P}$ value & 0.00172 & 0.93178 & 0.34766 \\
\hline \multirow[t]{5}{*}{$6-12 \mathrm{~h}$} & $2^{\wedge}(-\operatorname{Avg} \cdot(\operatorname{Delta}(\mathrm{Ct}))$ & 0.1133 & 0.0032 & 0.0017 \\
\hline & Fold Change & 108.32 & 22.69 & 15.22 \\
\hline & Fol Regulation & 108.32 & 22.69 & 15.22 \\
\hline & $95 \% \mathrm{CI}$ & (38.81. 177.83) & $(0.00001 .56 .42)$ & $(0.00001 .40 .26)$ \\
\hline & $* \mathrm{P}$ value & 0.00001 & 0.00174 & 0.04519 \\
\hline
\end{tabular}

*P values evaluated by independent sample $\mathrm{T}$ test with comparing control samples $2^{\wedge}(-\mathrm{Avg}$.(Delta(Ct))

$2^{\wedge}(-\operatorname{Avg}$.(Delta(Ct)) of control group; miR-1: 0.001046, miR-133a: 0.000139 and miR-133b: 0.000109

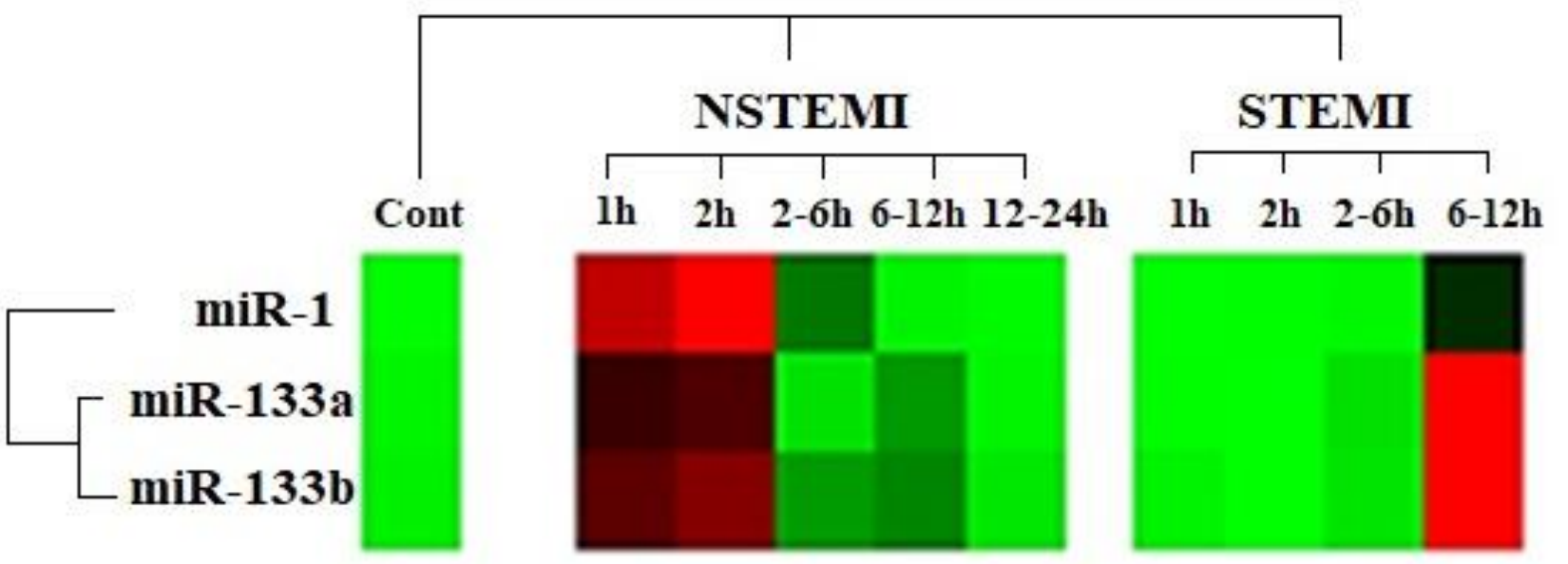

Magnitude of miRNA expression

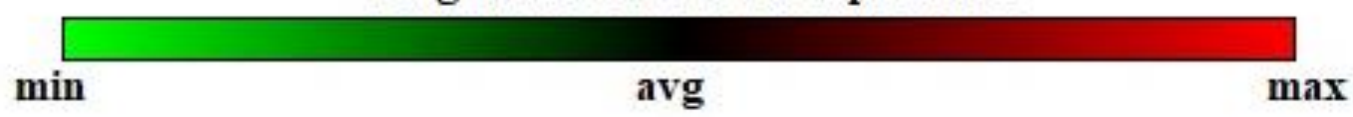

Fig. 1. Different expression profile of miR-1, miR-133a and miR-133 between STEMI and NSTEMI

Helsinki Declaration. All the participants in this study provided written informed consent.

RNA Extraction from Peripheral Blood Samples and RT-qPCR: Peripheral blood samples were taken from a peripheral vein of each patient with vein puncture and collected in $2 \mathrm{~mL}$ EDTA-coated tubes.
MiRNA was extracted from the peripheral blood samples through miRVana miRNA isolation kit (Thermo Fisher Scientific, Wilmington, Delaware, USA) according to the manufacturer's instructions. The amount and purity of miRNA for the samples were determined using the Nanodrop 2000 
Table 4. Time dependent miRNA expressions in NSTEMI cases

\begin{tabular}{|c|c|c|c|c|}
\hline & & miR-1 & miR-133a & miR-133b \\
\hline \multirow[t]{5}{*}{$1 \mathrm{~h}$} & $2^{\wedge}(-\operatorname{Avg} .(\operatorname{Delta}(\mathrm{Ct}))$ & 0.2393 & 0.0020 & 0.0012 \\
\hline & Fold Change & 228.73 & 14.12 & 10.55 \\
\hline & Fol Regulation & 228.73 & 14.12 & 10.55 \\
\hline & $95 \%$ CI & $(0.00001 .558 .57)$ & $(0.00001 .34 .90)$ & $(0.00001 .22 .75)$ \\
\hline & $* \mathrm{P}$ value & 0.07931 & 0.02592 & 0.08067 \\
\hline \multirow[t]{5}{*}{$2 \mathrm{~h}$} & $2^{\wedge}(-$ Avg. $(\operatorname{Delta}(\mathrm{Ct}))$ & 0.2734 & 0.0021 & 0.0013 \\
\hline & Fold Change & 261.30 & 14.94 & 11.70 \\
\hline & Fol Regulation & 261.30 & 14.94 & 11.70 \\
\hline & $95 \% \mathrm{CI}$ & $(0.00001 .561 .58)$ & $(0.00001 .41 .95)$ & (0.00001. 29.36) \\
\hline & $* \mathrm{P}$ value & 0.00002 & 0.01330 & 0.17798 \\
\hline \multirow[t]{5}{*}{$2-6 \mathrm{~h}$} & $2^{\wedge}(-\operatorname{Avg} \cdot(\operatorname{Delta}(\mathrm{Ct}))$ & 0.0727 & 0.0007 & 0.0005 \\
\hline & Fold Change & 69.46 & 4.99 & 4.12 \\
\hline & Fol Regulation & 69.46 & 4.99 & 4.12 \\
\hline & $95 \% \mathrm{CI}$ & $(0.00001 .152 .66)$ & $(0.00001 .12 .67)$ & (0.00001. 9.83) \\
\hline & $* \mathrm{P}$ value & 0.00033 & 0.60984 & 0.98407 \\
\hline \multirow[t]{5}{*}{$6-12 \mathrm{~h}$} & $2^{\wedge}(-\operatorname{Avg} \cdot(\operatorname{Delta}(\mathrm{Ct}))$ & 0.0056 & 0.0003 & 0.0004 \\
\hline & Fold Change & 5.32 & 1.90 & 3.47 \\
\hline & Fol Regulation & 5.32 & 1.90 & 3.47 \\
\hline & $95 \% \mathrm{CI}$ & (0.00001. 17.63) & $(0.00001 .4 .25)$ & $(0.25 .6 .70)$ \\
\hline & $* \mathrm{P}$ value & 0.02244 & 0.59304 & 0.69332 \\
\hline \multirow[t]{5}{*}{$12-24 \mathrm{~h}$} & $2^{\wedge}(-\operatorname{Avg} \cdot(\operatorname{Delta}(\mathrm{Ct}))$ & 0.0019 & 0.0001 & 0.0001 \\
\hline & Fold Change & 1.78 & 1.04 & 1.29 \\
\hline & Fol Regulation & 1.78 & 1.04 & 1.29 \\
\hline & $95 \% \mathrm{CI}$ & $(0.00001 .6 .58)$ & $(0.00001 .2 .60)$ & $(0.00001 .3 .30)$ \\
\hline & $* \mathrm{P}$ value & 0.05571 & 0.66893 & 0.72384 \\
\hline
\end{tabular}

*P values evaluated by independent sample $\mathrm{T}$ test with comparing control samples $2^{\wedge}(-\mathrm{Avg}$.(Delta(Ct))

$2^{\wedge}$ (-Avg.(Delta(Ct)) of control group; miR-1: 0.001046, miR-133a: 0.000139 and miR-133b: 0.000109

spectrophotometer (Thermo Fisher Scientific). MiRNA was transcribed to cDNA using miRCURY LNA ${ }^{\mathrm{TM}}$ Universal RT microRNA PCR System, FirstStrand cDNA Synthesis Kit (Exicon, Woburn, MA, USA) considering the protocol of the manufacturer. miRNAs were quantified by RT-qPCR using microRNA LNATM PCR primer sets (Exicon), considering the protocol of the manufacturer. Data were analyzed with the Light Cycler 480II software (Roche Diagnostics, Indianapolis, USA) with automatic setting for assigning baseline. The $2^{-\Delta \mathrm{Ct}}$ method was used to calculate the fold change in miRNA expression between the tested samples (10).

Statistical Analysis: RT2 Profiler PCR Array Data Analysis

(http://www.sabiosciences.com/pcr/arrayanalysis.ph p) was used to compare the results of the miRNA expression analysis with characteristics of STEMI and NSTEMI patients. Fold differences $\geq 2$ between miRNA expressions was considered significant.
Correlation analyses of paired sample t-test were performed to analyze the correlations between timedependent miRNA expressions and biochemical parameters with SPSS 20 statistical software (IBM SPSS Inc, Chicago, IL, USA). Confidence intervals of 95\% were calculated with the associated estimated standard errors. A p-value $<0.05$ was considered statistically significant.

\section{Results}

Patient Characteristics: In this study, 27 of the patients diagnosed with acute STEMI (61.41 2.71 years old) and 27 of the patients diagnosed with NSTEMI (60.48 \pm 2.39 years old). 33.3\%, 3.7\%, $29.6 \%, 5.5 \%$ and $25.9 \%$ of patients were formerly diagnosed with coronary heart disease, obesity, arterial hypertension, hyper lipid and diabetes mellitus respectively. $29.6 \%$ of patients were cigarette dependent, and $9.3 \%$ of the patients had the family history. After feeling chest pain, 19 (35.2\%) patients 
Tezcan ve ark. / miRNA expression patterns of ACS

Table 5. Correlation of CK-MB and miRNA expressions in NSTEMI and STEMI

\begin{tabular}{cccccc}
\hline & \multirow{2}{*}{ CK-MB } & \multicolumn{2}{c}{ NSTEMI } & \multicolumn{2}{c}{ STEMI } \\
\cline { 2 - 5 } & $1 \mathrm{~h}$ & Correlation & $*$ P value & Correlation & $*$ P value \\
\hline \multirow{4}{*}{ miR-1 } & $2 \mathrm{~h}$ & -0.142 & 0.697 & 0.152 & 0.697 \\
& $2-6 \mathrm{~h}$ & -0.971 & 0.233 & 0.232 & 0.768 \\
& $6-12 \mathrm{~h}$ & -0.140 & 0.029 & 0.164 & 0.629 \\
& $12-24 \mathrm{~h}$ & -0.412 & 0.860 & 0.987 & 0.102 \\
miR-133a & $1 \mathrm{~h}$ & -0.189 & 0.417 & - & - \\
& $2 \mathrm{~h}$ & -0.351 & 0.601 & 0.278 & 0.468 \\
& $2-6 \mathrm{~h}$ & -0.997 & 0.772 & 0.383 & 0.617 \\
& $6-12 \mathrm{~h}$ & -0.208 & 0.792 & 0.604 & 0.049 \\
& $12-24 \mathrm{~h}$ & -0.520 & 0.290 & 0.957 & 0.188 \\
miR-133b & $1 \mathrm{~h}$ & -0.076 & 0.835 & - & - \\
& $2 \mathrm{~h}$ & -0.999 & 0.022 & 0.168 & 0.666 \\
& $2-6 \mathrm{~h}$ & -0.938 & 0.062 & 0.364 & 0.636 \\
& $6-12 \mathrm{~h}$ & -0.495 & 0.505 & 0.462 & 0.483 \\
& $12-24 \mathrm{~h}$ & -0.472 & 0.344 & - & 0.694 \\
\hline
\end{tabular}

*P values evaluated using correlation analyses of paired samples $T$ test

Table 6. Correlation of Troponin T and miRNA expressions in NSTEMI and STEMI

\begin{tabular}{cccccc}
\hline & Troponin $\mathrm{T}$ & \multicolumn{2}{c}{ NSTEMI } & \multicolumn{2}{c}{ STEMI } \\
& & Correlation & $*$ P value & Correlation & *P value \\
\hline \multirow{2}{*}{ miR-1 } & $2 \mathrm{~h}$ & -0.177 & 0.624 & -0.151 & 0.698 \\
& $2-6 \mathrm{~h}$ & 0.989 & 0.094 & 0.919 & 0.081 \\
& $6-12 \mathrm{~h}$ & -0.977 & 0.023 & 0.204 & 0.547 \\
& $12-24 \mathrm{~h}$ & $-0,325$ & 0.998 & 0.999 & 0,026 \\
miR-133a & $1 \mathrm{~h}$ & -0.225 & 0.530 & - & - \\
& $2 \mathrm{~h}$ & -0.155 & 0.532 & -0.340 & 0.370 \\
& $2-6 \mathrm{~h}$ & -0.998 & 0.002 & 0.524 & 0.476 \\
& $6-12 \mathrm{~h}$ & 0.440 & 0.560 & 0.572 & 0.066 \\
miR-133b & $13-24 \mathrm{~h}$ & -0.366 & 0.476 & -0.984 & 0.113 \\
& $1 \mathrm{~h}$ & -0.110 & 0.761 & -0.386 & - \\
& $2 \mathrm{~h}$ & 0.853 & 0.349 & 0.463 & 0.304 \\
& $2-6 \mathrm{~h}$ & -0.946 & 0.054 & 0.075 & 0.827 \\
& $6-12 \mathrm{~h}$ & 0.689 & 0.311 & -0.563 & 0.619 \\
\hline
\end{tabular}

$* \mathrm{P}$ values evaluated using correlation analyses of paired samples $\mathrm{T}$ test

within one hour, 7 (12.9\%) patients within 2 hours, 15 $(27.8 \%)$ patients within 3 to 6 hours, $7(12.9 \%)$ patients within 6 to 12 hours and $6(11.2 \%)$ patients within 12 to 24 hours admitted to the emergency department. Accordingly, patients were divided into five individual groups. Distribution of these patients is shown in Table 1.

Time-dependent Expression Status of Circulated miRNA in ACS: In the whole population statistics, the expression of miR-1 was 6.91 fold, miR-133a was
2.73 fold, and miR-133b was 2.65 fold upregulated in ACS patients in compare to control group $(\mathrm{P}=$ $0.40509 ; \mathrm{P}=2.31700$ and $\mathrm{P}=0.56716$; respectively). However, the expression levels of these miRNAs fluctuated time dependently. From 1st hour to 12th hour the expression level of miR-1 was up-regulated in all patients $(\mathrm{p}<0.05$ or fold change $>2)$ in comparison to control group. However, between 12th and 24th hours, the expression level was in normal levels. miR-133a and miR-133b were up-regulated in 
$\mathbf{A}$

NSTEMI

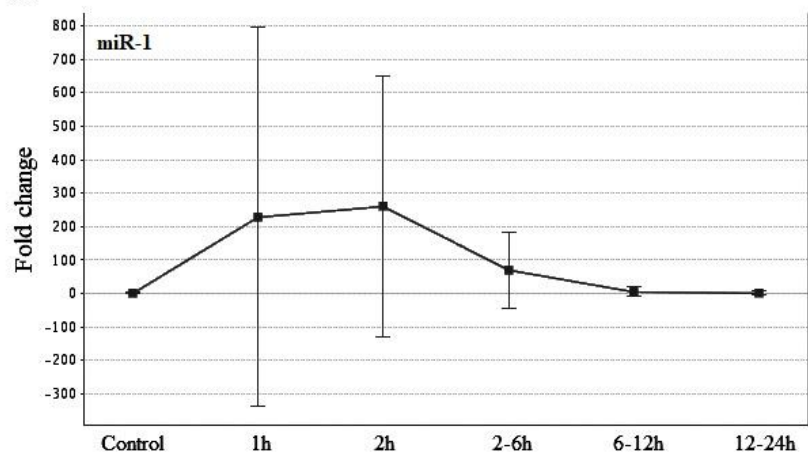

C

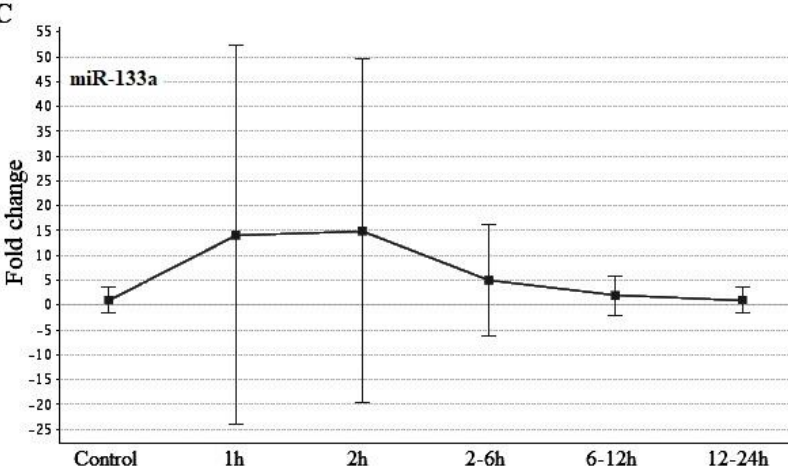

$\mathbf{E}$

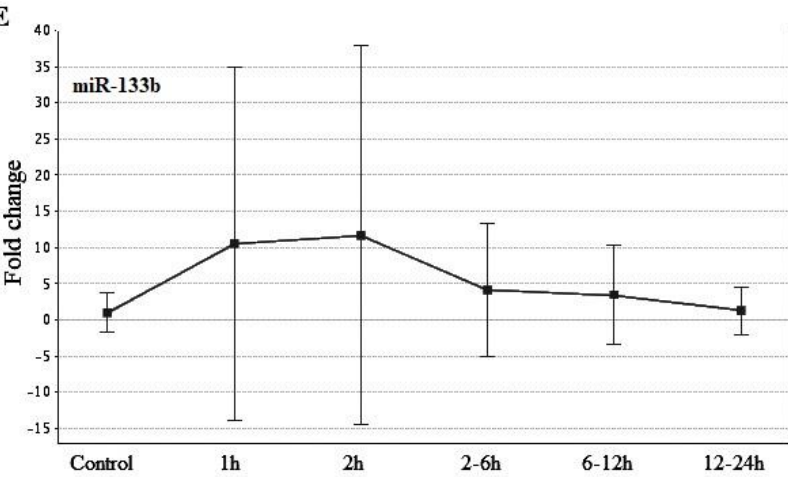

B

STEM

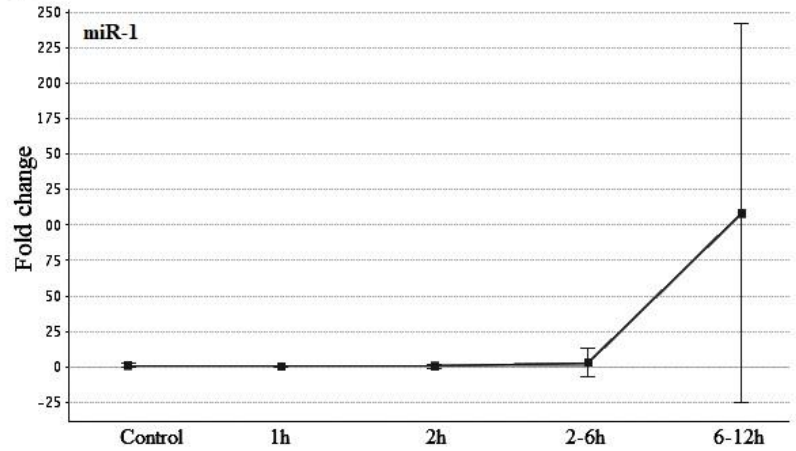

D

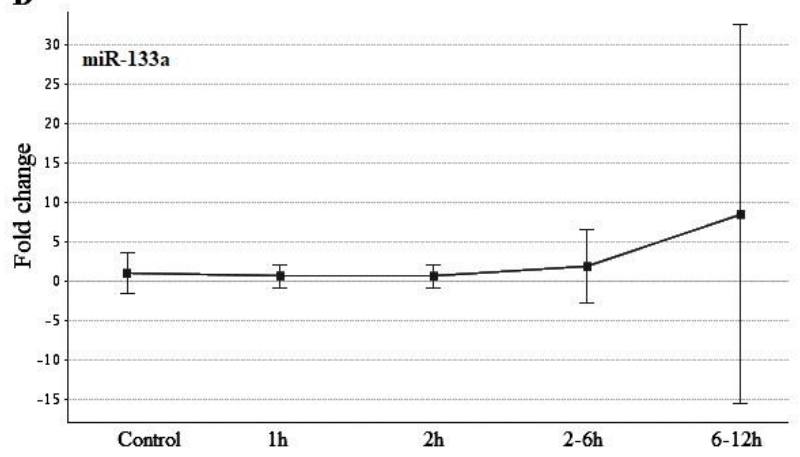

$\mathbf{F}$

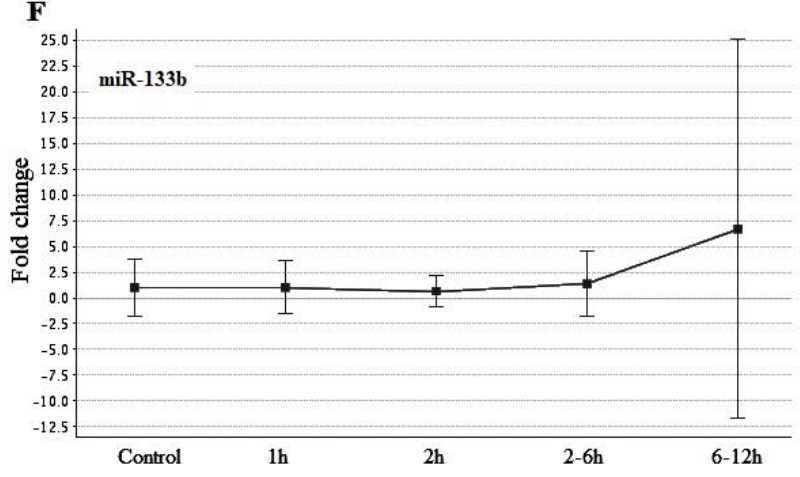

Fig. 2. Time dependent fold regulations of miR-1, miR-133a and miR-133b

first 2 hours and within 6th to 12th hours. In 3th to 5 th hours and after 12th hours their expressions were in normal levels (Table 2).

When the expression levels of these miRNAs were evaluated comparatively between STEMI and NSTEMI patients, the time-dependent fluctuation of miRNA regulations disappeared, and unique, distinctive expression patterns were observed in STEMI and NSTEMI patients (Figure 1). In comparison to control group, the expression of miR-1 was 5.87 fold and 2.65 down-regulated in STEMI subjects within the first two hours of chest pain. $(\mathrm{P}=$ 0.19630 and $\mathrm{P}=0.07963$; respectively). However, the expression of miR-1 began to increase after the second hour; between 2th and 6th hours its expression observed 2.98 fold more than the control group $(\mathrm{P}=0.00172)$ and following hours from 6th to 12th hour the expression of this miRNA was 108.32 fold upregulated $(\mathrm{P}=0.00001)$. MiR-133a and miR$133 \mathrm{~b}$ demonstrated a similar expression curve with miR-1. Similarly, their expressions were downregulated in the first couple of hours and between 2 th and 6th hours although they were still in normal expression levels, they turned to increase. After 6th hours, miR-133a was 22.69 fold, miR-133b was 15.22 fold upregulated $(\mathrm{P}=0.00174$ and $\mathrm{P}=0.04519$; respectively, Table 3).

The regulations of the miRNAs were in an opposite direction in NSTEMI cases to STEMI cases (Figure 2). In case of NSTEMI, in compare to control group, the expression of miR-1 was significantly increasing within first two hours of chest pain (in 1st hour: 228.73 fold. $\mathrm{P}=0.07931$; in 2 nd hour: 261.30 fold. $\mathrm{P}=$ 0.00002). However, after the second hour, the 
expression of miR-1 tended to decrease. Between 2nd and 6th hours its expression observed 69.46 fold $(\mathrm{P}=0.00033)$ and between 6th to 12th hour it was 5.32 fold upregulated $(\mathrm{P}=0.02244)$. Following hours from 12th to 24th hour the expression of this miRNA was in normal levels (1.78 fold; $\mathrm{P}=0.05571)$. In addition, the expression of miR-133a and miR-133b were significantly upregulated in six hours with a tendency to decrease. miR-133a in between 6th and 12th hours and miR-133b in between 12th to 24th hours decreased to normal expression levels (Table 4, Figure 2).

Correlation Between Diagnostic Parameters and miRNA Expressions: The expressions of miR-1, miR-133a and miR-133b were in negative correlation with CK-MB in NSTEMI group and were in positive correlation in STEMI group (P> 0.05; Table 5). However, there was no correlative association between Troponin $\mathrm{T}$ levels and miRNA expression neither in STEMI nor NSTEMI patients (Table 6).

\section{Discussion}

In the treatment and prognosis of ACS, rapid and correct diagnosis is crucial. Cardiac troponins and CK-MB are the most commonly used biomarkers for ACS. However, their clinical value is limited (11). Recent studies highlighted the role of altered miRNA expressions in the formation of cardiac diseases (11, 12). Some of these miRNAs, such as miR-1, miR$133 \mathrm{a}$ and miR-133b, which are expressed in heart tissue, are also associated with ACS $(11,12)$. Although these miRNAs are expressed in heart tissue, secretoms of heart tissue cells, such as microvesicles, exosomes, microparticles and lipoprotein complexes, consist of these miRNAs and can be detected in serum or plasma. Circulating muscle-derived miRNAs may leak out of the necrotic myocardium and release into the circulation during the early stages of ACS (13-15).

MiRNA levels in serum or plasma remain stable in prolonged room temperature incubation or freezethawed multiple times $(11,16)$. Therefore, miRNAs which are secreted by cardiac cells and accumulated in the blood may provide unique knowledge to contribute understanding of mechanism of ACS and may open a new frame for diagnostic and therapeutic interventions (17). Wang et al. (18) showed that the levels of muscle-enriched miR-1 increased in plasma of rats and human with ACS and showed a positive correlation with serum CK-MB level. On the other hand, in another clinical study from Cheng et al. (19) demonstrated that although plasma miR-1 level was significantly higher in ACS patients compared with non-ACS subjects, the increased plasma miR-1 was not in correlation with serum CK-MB level. Our were compatible with the studies that showed that levels of the circulating miR-1was 6.91 fold increased in ACS patients and was significantly higher than those in healthy volunteers $(P=0.40509)$. However, the fold regulation of this miRNA fluctuated timedependently.

It is notable that reports on the regulation of circulating miR-133 in ACS are controversial. Wang et al. found out that miR-133 in increased levels in plasma of rats and human with ACS and reported a positive correlation with serum Troponin I (24). However, Ai et al.'s research showed that there was no significant difference in plasma level of miR-133 between ACS patients and healthy subjects (20). In the present study, the expression level of miR-133a and miR-133b were 2.73 fold and 2.65 fold upregulated in plasma of ACS patients. Although in this frame our data support Wang et al.'s findings, the fold regulations of these miRNAs were also fluctuated time dependently.

As reported above, there are several studies that underline the altered expressions of miR-1, miR-133a and miR-133b in ACS. However, the knowledge about their distinct regulation pattern in STEMI and NSTEMI is still insufficient. The diagnostic factors of ACS may also demonstrate different patterns between STEMI and NSTEMI cases. Evaluation of these cases individually may clarify the current inconsistent data about their miRNA expression profile. Therefore, in the present study, we evaluated the different expression pattern of miR-1, miR-133a and miR-133b between STEMI and NSTEMI cases comparatively. Our findings showed that these miRNAs regulation is in the opposite direction between STEMI and NSTEMI. In STEMI patients, in the first 2 hours miR-1 was 5.87 and 2.65 folds down-regulated and became observable between 2th and 6th hours (2.98 fold) and between 6th and 12th hours, it was significantly (108.35 fold) induced $(\mathrm{P}<0.05)$. Inversely; in NSTEMI patients, in the first 2 hours miR-1 was 228.73 fold and 261.30 fold higher than control subjects. However, between 2th and 6th hours, the expression of miR-1 reduced to 69.46 fold, between 6th to 12th hours it reduced to 5.32 fold $(\mathrm{P}<0.05)$ and after 12 hours it reduced to similar levels of control subjects. MiR-133a and miR-133b were also demonstrated similar expression patterns with miR-1 in STEMI and NSTEMI cases. In the first 6 hours of STEMI, there were no significant differences between the expression of these miRNAs and control subjects (fold regulation $<2$ fold). However, from 6th to 12th hours their expressions were considerably increased (22.69 fold and 15.22 fold, respectively; $\mathrm{P}<0.05)$. On the other hand; these 
miRNAs were in high levels during the first six hours of ACS in NSTEMI patients. MiR-133a decreased to normal levels following times of the 6th hour, and miR-133b decreased to normal levels between 12th and 24th hour. Thus, our data demonstrated that, in STEMI, and NSTEMI patients the expression levels of these miRNAs might change in different directions depending on measuring time. This finding may clarify the reason for time-dependent fluctuation in the expression level of these miRNAs in the evaluation of whole patients in the same sample group.

Troponin $\mathrm{T}$ is a part of troponin complex expressed in skeletal and cardiac myocytes. The cardiac subtype of troponin $\mathrm{T}$ is released into the blood stream when heart muscle damaged (21). CK isozymes provide specific information about the localization of tissue injury. CK enzymes rise when muscle cells damaged in the body. CK-MB is presented, to various degrees, in heart muscle ( $25 \%$ to $46 \%$ of CK activity) and also to a minor degree in skeletal muscle $(<5 \%)(22,23)$. In people with chest pain, total $\mathrm{CK}$ and CK-MB levels are measured to realize a potential heart attack. Because total CK height indicates damage to the heart or other muscles, CK-MB helps distinguish these two damaged areas. CK-MB is $2-3 \%$ of total serum CK. If CK-MB exceeds $6 \%$, it is accepted as pathological values. In ACS, usually, total CK starts to increase in 3-4 hour following chest pain, reaches the maximum in 24 hours and decrease to normal values in three days (24). Current knowledge about the diagnostic factors of ACS and miRNA is also insufficient. Cheng et al. (19) did not find out any link between plasma miR-1 expression and CK-MB. On the other hand, a positive correlation was reported between the elevated plasma miR-133 and Troponins. Plasma levels of miR-133a and miR-133b were reported as upregulated in STEMI patients about 156 minutes after the occurrence of ACS, consistent with the time course of change in Troponin $\mathrm{T}$ level $(14,25)$. Approximately two-thirds of ACS occurs outside the hospital, and most of these patients apply to the hospital not immediately but within 24 hours after feeling the chest pain. Thus, the association of altered expressions of miR-1, miR-133a and miR-133b and diagnostic factors of ACS may be time depended. Therefore, in the present study, we evaluated the different expression pattern of miR-1, miR-133a and miR-133b and the association of these miRNAs with diagnostic factors of ACS, such as Troponin T and CK-MB in STEMI and NSTEMI cases in a time depended manner. Unlikely to previous studies, in STEMI patients, miR-1, miR-133a and miR-133b were in positive correlation with CK-MB during the first 12 hours. Due to any STEMI patients did not apply to emergency department between 12th and 24th hours of chest pain, we could not evaluate the correlation of these miRNAs with other diagnostic factors of ACS for this time period. On the other hand, in case of NSTEMI, as expected, the expressions of miRNAs were in negative correlation with CK-MB during the first 24 hours. However, we could not determine a continue correlation with a stability between miRNAs and Troponin T.

In conclusion, supporting previous literature, we identified that, circulating miR-1, miR-133a and miR$133 \mathrm{~b}$ expressions were significantly increased in ACS cases. We demonstrated the considerably higher expression levels of these miRNAs in NSTEMI cases in compare to STEMI cases during the first 6 hours of chest pain. We also defined that although these miRNA expressions increase during ACS in both STEMI and NSTEMI patients, their expression pattern differs between these two groups of patients depend on the time of evaluation. While miRNA expressions were in positive correlation with CK-MB in STEMI, they were in negative correlation in NSTEMI patients for the first 24 hours. Hence, we suggest that time dependent miR-133a and miR-133b expression pattern of ACS patients are likely to guess the progression of coronary heart disease. Advanced functional and in-vivo studies to evaluate the association between the miRNA carrier vesicle releasing time of heart tissue and their expression levels in peripheral blood and larger cohort validations are required.

\section{References}

1. Amsterdam EA, Wenger NK, Brindis RG, Casey DE Jr, Ganiats TG, Holmes DR Jr, et al. 2014 AHA/ACC guideline for the management of patients with non-ST-elevation acute coronary syndromes: a report of the American College of Cardiology/American Heart Association Task Force on Practice Guidelines. Circulation 2014; 130(25): 344-426.

2. Ölüm Nedeni İstatistikleri, 2016, Türkiye İstatistik Kurumu, http:/ /www.tuik.gov.tr/PreHaberBultenleri.do?id $=24572$ (ET: 27.04.2017)

3. Kontos MC, Diercks DB, Kirk JD. Emergency department and office-based evaluation of patients with chest pain. Mayo Clin Proc 2010; 85(3): 284-299.

4. Aradi D, Tornyos A, Pinter T, Vorobcsuk A, Konyi A, Falukozi J, et al. Optimizing P2Y12 receptor inhibition in patients with acute coronary syndrome on the basis of platelet function testing: impact of prasugrel and high-dose clopidogrel. J Am Coll Cardiol 2014; 63(11): 1061-1070. 
5. Loria V, Leo M, Biasillo G, Dato I, Biasucci LM. Biomarkers in Acute Coronary Syndrome. Biomark Insights 2008; 3: 453-68.

6. Lloyd-Jones D, Adams R, Carnethon M, De Simone G, Ferguson TB, Flegal K, et al. Heart disease and stroke statistics-2009 update. A report from the American Heart Association Statistics Committee and Stroke Statistics Subcommittee. Circulation 2009; 119: 21-182.

7. Zdzienicka J, Siudak Z, Zawiślak B, Dziewierz A, Rakowski T, Dubiel J, et al. Patients with non-STelevation myocardial infarction and without chest pain are treated less aggressively and experience higher in-hospital mortality. Kardiol Pol 2007; 65(7): 769-777.

8. Braunwald E, Antman EM, Beasley JW, Califf RM, Cheitlin MD, Houchman JS, et al. ACC/AHA guidelines for the management of patients with unstable angina and non-STsegment elevation myocardial infarction: executive summary and recommendations. A report of the American College of Cardiology/American Heart Association task force on practice guidelines (committee on the management of patients with unstable angina). Circulation 2000; 102(10): 11931209.

9. Small EM, Frost RJ, Olson EN. MicroRNAs add a new dimension to cardiovascular disease. Circulation 2010; 121(8): 1022-1032.

10. Livak KJ, Schmittgen TD. Analysis of relative gene expression data using realtime quantitative PCR and the 2(-Delta Delta C(T)) method. Methods 2001; 25(4): 402-408.

11. Sayed AS, Xia K, Yang TL, Peng J. Circulating microRNAs: a potential role in diagnosis and prognosis of acute myocardial infarction. Dis Markers. 2013; 35(5): 561-566.

12. Clauss S, Wakili R, Hildebrand B, Kääb S, Hoster E, Klier I, et al. MicroRNAs as Biomarkers for Acute Atrial Remodeling in Marathon Runners (The miRathon Study-A Sub-Study of the Munich Marathon Study). PLoS One 2016; 9: 0148599.

13. Bostjancic E, Zidar N, Stajer D, Glavac D. MicroRNAs miR-1, miR-133a, miR-133b and miR-208 are dysregulated in human myocardial infarction. Cardiology 2010; 115(3): 163-169.

14. D'Alessandra Y, Devanna P, Limana F, Straino S, Di Carlo A, Brambilla PG, et al. Circulating
microRNAs are new and sensitive biomarkers of myocardial infarction. Eur Heart J 2010; 31(22): 2765-2773.

15. Dimmeler S, Zeiher AM. Circulating microRNAs: novel biomarkers for cardiovascular diseases? Eur Heart J 2010; 31(22): 2705-2707.

16. Zheng HW, Wang YL, Lin JX, Li N, Zhao XQ, Liu GF, et al. Circulating MicroRNAs as potential risk biomarkers for hematoma enlargement after intracerebral hemorrhage. CNS Neurosci Ther 2012; 18(12): 1003-1011.

17. Meder B, Keller A, Vogel B, Haas J, SedaghatHamedani F, Kayvanpour E, et al. MicroRNA signatures in total peripheral blood as novel biomarkers for acute myocardial infarction. Basic Res Cardiol 2011; 106(1): 13-23.

18. Wang GK, Zhu JQ, Zhang JT, Li Q, Li Y, He J, et al. Circulating microRNA: a novel potential biomarker for early diagnosis of acute myocardial infarction in humans. Eur Heart J 2010; 31(6): 659-666.

19. Cheng Y, Tan N, Yang J, Liu X, Cao X, He P, et al. A translational study of circulating cell-free microRNA-1 in acute myocardial infarction. Clin Sci (Lond) 2010; 119(2): 87-95.

20. Ai J, Zhang R, Li Y, Pu J, Lu Y, Jiao J, et al. Circulating microRNA-1 as a potential novel biomarker for acute myocardial infarction. Biochem Biophys Res Commun 2010; 391(1): 7377.

21. Mann D, Zipes D, Libby $\mathrm{P}$, Bonow $\mathrm{R}$. Braunwald's Heart Disease: A Textbook of Cardiovascular Medicine, Single Volume. 10 ${ }^{\text {th }}$ ed. Philadelphia (PE): Saunders Elsever; 2014.

22. Moss DW, Henderson AR. Clinical enzymology. In: Brutis CA, Ashwood ER, eds. Tietz Textbook of Clinical Chemistry. 3th ed. Philadelphia (PE): W.B. Saunders Co; 1999.

23. Takagi Y, Yasuhara T, Gomi K. Creatine kinase and its isozymes. Rinsho Byori 2001; 116: 52-61.

24. Pierce GF, Jaffe AS. Increased creatine kinase MB in the absence of acute myocardial infarction. Clin Chem 1986; 32(11): 2044-2051.

25. Hunter MP, Ismail N, Zhang X, Aguda BD, Lee EJ, $\mathrm{Yu}$ L, et al. Detection of microRNA expression in human peripheral blood microvesicles. PLoS One 2008; 3: 3694. 